\title{
DANUTA SOSNOWSKA
}

Institute of Western and Southern Slavic Studies

University of Warsaw

\section{SVATÝ JAN POD SKALOU: THE SACRED PLACE AND CONFLICTED TRADITIONS}

Keywords: tourist guide, spirituality, philosophy of Czech history, Saint John under the Rock, communism

Słowa kluczowe: przewodnik turystyczny, duchowość, filozofia dziejów Czech, Święty Jan pod Skałą, komunizm

\section{Su m m a ry}

The author explores the ideologization of human space on the example of the place known as Saint John under the Rock in Czechia. This place has a long and rich tradition, also written one, and is tightly bound with Czech identity, not only local but also national. The oldest mentions about the place appear in medieval manuscripts that describe it as one of the most mysterious and sacred. Religious tradition connected with the place serves as an example of the diversity of Czech approaches to faith. For the history of the place was extremely turbulent and its owners usually used it as a tool of cultural appropriation and ideological interest, Saint John under the Rock proves how desired traditions were shaped. To discuss Czech tradition, the author employs the metaphor of "geological layers." Although all the layers - the Christian, the secular, and even the communist tradition - compose Czech identity, their interpreters analyze them in separation. They detach the layer of tradition that does not fit their perspective. Hence, the place under analysis reveals a battle for identities that aims to establish the dominant layer of tradition. In this article, I seek to unveil the game of contradicting narratives to show how a place so deeply plunged in Czech tradition is abused to represent only a part of the "right" tradition.

\section{ŚWIĘTY JAN POD SKAŁĄ: ŚWIĘTE MIEJSCE I JEGO SKONFLIKTOWANE TRADYCJE}

\section{Streszczenie}

Autorka zajmuje się problemem ideologizacji przestrzeni na przykładzie miejsca znanego w Czechach jako Święty Jan pod Skałą. Miejsce posiada długą i bogatą tradycję, także pisaną. Najstarsze wzmianki o nim można znaleźć w średniowiecznych manuskryptach, ukazujących to miejsce jako jedno z najbardziej tajemniczych i świętych. Religijne tradycje, które są z nim związane 
mogą służyć za przykład złożoności czeskiego stosunku do wiary. Ponieważ historia tego miejsca była burzliwa, a ci, którzy na pewien czas uzyskiwali nad nim władzę, używali go jako narzędzia dla swoich kulturowych koncepcji i/lub politycznych interesów, Święty Jan pod Skałą może służyć za dowód tego jak kształtowano pożądane tradycje. Autorka odnosi się do metafory, która pokazuje czeską tradycję jako geologicznej struktury, na którą składają się różne warstwy. Choć one wszystkie (zarówno chrześcijańska tradycja, jak i świecka, laicka, a nawet komunistyczna, tworzyły czeską tożsamość, ich interpretatorzy odnosili się do nich w sposób wykluczający. Odkładali na bok te warstwy tradycji, które nie pasowały do ich światopoglądu. W ten sposób miejsce pokazuje batalie o tożsamość, z jednoczesnym zamiarem ustanowienia tylko jednej jej formy formą dominującą.

1.

Travelling, visiting, and seeing are different stages of the same tourist activity, connected with and complementing each other. However, this is an idealistic opinion because very often observing and learning a country does not mean seeing a lot. The question "How much can an average tourist recognize during travels?" was posed by two Czech writers, Jiří Kuchař and Václav Vokolek. The two started from the premise that people look only at what is around them, on the surface, visible and touchable. Tourists cannot see or know of the underworld that exists under their feet. Despite this typical blindness, the hidden endures, and every country has its own geographical and historical underworld. Unaware, the tourist is deprived of substantial contact with the visited places. Both authors reveal no apprehension about "touristicization," which is now very often connected with the conventional globalized trivialization of the world supported by the media. Nevertheless, Kuchař and Vokolek show how any tourist may see more and look deeper.

The conviction of Kuchař and Vokolek resulted in the unusual tourist guide Esoterické Čechy, Morava a Slezsko (Esoteric Czechia, Moravia, and Silesia). ${ }^{1}$ The first volume was published in 2002, the last till now - in 2008, altogether nine volumes. Each volume presents different regions of the Czech Republic, but one specific feature connects all these regional descriptions: every region has its mystical and mysterious history, which may and should be revealed. From that point of view, visible places are, in fact, a curtain that covers the spiritual countryside hidden from human sight. We may say that the work of Kuchař and Vokolek offer a guide to the spiritual underground land of Czechia, Moravia, and Silesia. Moreover, the authors included the places usually perceived as unattractive to tourists like the regions devastated by heavy industry. ${ }^{2}$

\footnotetext{
${ }^{1}$ Jiř́i Kuchař, Václav Vokolek, Esoterické Čechy, Morava a Slezsko, vol. 1 (Praha: Eminent, 2002).

${ }^{2}$ Jiří Kuchař, Václav Vokolek, Esoterické Čechy, Morava a Slezsko, vol. 4 (Praha: Eminent, 2005).
} 
For instance, the Kladno region usually holds nothing of interest for tourists, but the authors prove how precious and worthwhile it can be should one acknowledge its sacred, metaphysical tradition. Kuchař and Vokolek's idea for the guide surfaced from their conviction that the Czech people forgot their own history, that they are disinherited from their past and are unaware of what is essential to their existence. Václav Vokolek is the son of a Catholic poet, Vladimír Vokolek, who was persecuted because of his political and religious views under communism. Vokolek became the cicerone of Czechia's immaterial reality. Kuchař and Vokolek encourage any tourist not only to be a traveler but also a seeker or even - a tradition digger.

In its approach to spirituality, Esoterické Čechy, Morava a Slezsko undoubtedly represents popular culture, even sensational culture. However, I will refer to a more sophisticated cultural concept for more elitist receivers formulated by a Czech theologian and intellectual, Karel Skalický. Noteworthy, regardless of all the differences between Skalický's idea and Vokolek's project, there share one similarity: the geological vision of culture, which is to keep some of its strata hidden. The cultural vision of Skalický matured as a result of his personal experiences and historical circumstances. Skalický emigrated from Czechoslovakia in 1956, was ordained priest in 1961, served during the Second Vatican Council, and after 1968, when the troops of the Warsaw pact suppressed the "Prague Spring," he became one of the most important people in the circle of Czech Christian intelligentsia in Rome, the editor-in-chief of the Studie journal, engaged in fight against totalitarianism. In his article "Prolegomena k budoucí filozofii českých dějin" (Prolegomena to the Future Philosophy of Czech History), ${ }^{3}$ Skalický argues that "[Czech] national consciousness is neither homogenous nor unanimous, unvarying, but it is complex, varied, and varying, polyphonic. Hence, it definitely shows its multiple, stratified character that results in inner conflicts and tension." ${ }^{4}$ Elsewhere, Skalický refers to Jan Patočka: "continuation does not exist, it is necessary to take discontinuation as a premise and see in it the basis for consideration of Czech history."

While analyzing Skalickýs article, a Czech philosopher, theologian, and Catholic priest, Tomáš Halík, emphasizes this "geological" character of Czech culture, foregrounds some problems that arise from such stratification. Following Skalickýs thought, Halik indicates different sources and traditions that had been influencing Czech identity for ages, but are not perceived as components

\footnotetext{
${ }^{3}$ Karel Skalický, "Prolegomena k budoucí filozofii českých dějin,” in Karel Skalický, Za nadějí a smysl (Praha/Ř́m, 1996), 143-179. First published in Studie, no. 55 (1978): 23-56.

${ }^{4}$ Karel Skalický, op. cit., 172. Unless stated otherwise, the text is translated by Danuta Sosnowska.

${ }^{5}$ Ibidem.
} 
of a dynamic structure in which various and variable elements are complementary yet often competitive. Instead, those who described the essence of Czech culture were driven by their worldview that blinded them to everything else that did not match their point of view. Hence, they only selected one stratum of Czech culture in line with their opinions and, then, presented it as a distinctive feature and the core of Czech character. Halík appreciates Skalický's contribution to the discussed subject as an approach in utter opposition to the above. Although Skalický is a Catholic priest and theologian, he conferred cultural primacy neither to Catholicism nor Protestantism. According to Skalický, Catholic pretension to constitute the main tradition of Czech identity and similar Protestant aspiration are both aprioristic: "in an unaccountable way [both Churches] want history to represent only one idea, to have only one stream ... both construct their one-tradition chain from famous and honored people." 6

A tendency to exclusive discourses foregrounds the significance of liberal and Marxist layers in the Czech culture. They leave other cultural strata aside - marginalized, omitted, neglected. The leftist viewpoint excludes the memory of Christian Czech tradition. And vice versa, should there be a vision of Czechia that achieves its identity only through Christianity, it would erase the consciousness of how important the communist trend was for the country. Turbulent religious movements in Czechia made cultural description even more difficult. Czech Christian tradition divided into three parts. In the distant past, Byzantine competed with Latin influences, later the Czech reformation discredited the authority of the Catholic Church, only for the Catholic Church to eventually gain the upper hand. Each ideological domination evoked tendencies of exclusiveness and actions to expurgate the other cultural strata. Thus, exclusiveness became an important feature in the Czech culture.

The ideological impact of the exclusivist tendency appears obvious when we analyze the human space in Czechia. This impact visibly affects the place I selected to exemplify how human space meets ideology. The place I selected existed as the crossroads of different cultural traditions and can thus serve as an archaeological site for the observation of different cultural layers. However, instead of presenting cultural complexity and variety, the place proves how many apply discriminative narrative practices to cover unwelcome tradition. The name of the place is Svatý Jan pod Skalou, Saint John under the Rock.

"Saint John under the Rock" is a small village close to Prague, which still intrigues human imagination more than one would expect, considering the objective importance of this village. In a documentary Počesku: Svatý Jan

${ }^{6}$ Tomáš Halík, Víra a kultura - pokoncilní vývoj českého katolicismu v reflexi časopisu Studie (Praha: Zvon, 1995), 103. 
pod Skalou, Ves pod patronátem poustevníka, který se ovšem nejmenoval Jan (Saint John Under the Rock. Village Under the Patronage of the Hermit Who, However, Was not Named John), Václav Žmolík guides spectators to the mysterious place to say that the city has own genius loci because "everything there is different." 7

What does it mean? I think Svatý Jan pod Skalou fascinates not only as a conveyor of a mystical tradition or an example of the "esoteric Czechia" buried underground, out of sight. In my opinion, this place captivates because of the clash of different overlapping cultural and historic traditions. The historical and political history of the place was utterly turbulent. As it changed hands, the changing owners of Svatý Jan pod Skalou adapted the site to their own needs and ideological interests. They acted as its absolute "sovereigns." That is to say, the place was appropriated with its past and present, its owners assuming the right to create the space anew. Only fragments of its history were accepted by the people and remained, the rest was forgotten, neglected, or deformed, which could have only resulted in "a special new local product" - a newborn place that presents whatever those in power want it to highlight.

However, the subject is not especially interesting to those who now present the place in television and radio programs about the village or give tourist tips to readers. The protean story of the place sometimes surfaces in journalist descriptions but the excitement concerns its unusual mood, legends, ${ }^{8}$ and religious traditions (sometimes treated very seriously). ${ }^{9}$ There are numerous programs that praise the beauty of local nature and the countryside. ${ }^{10}$ The religious tradition of Svatý Jan pod Skalou does attract believers but also those who seek thrilling anecdotes, which offer the opportunity to show the grotesque of history or religious naivety. However, even those who mock local religiosity mix comedy with drama. A good example is the documentary Výprava za českými čerty. Pokušení svatého Ivana. Jaromír Štětina v osidlech

7 “Počesku: Svatý Jan pod Skalou, Ves pod patronátem poustevníka, který se ovšem nejmenoval Jan,” http://www.ceskatelevize.cz/ivysilani/1037067545-pocesku/201322225720003-svaty-jan-podskalou (acc. 5.05.2018).

${ }^{8}$ Vide "Příběh poustevníkova lože" commented by František Nepil (1995), realization Inka Ciprová and Jaromír Vašta (edited in Czech TV 2015, film unavailable).

${ }^{9}$ E.g., the program about Saint John under the Rock presented as part of a cycle depicting places of deep spiritual tradition in Czechia: "Cyklus o putování po známých i méně známých místech hlubokých tradic,” http://www.ceskatelevize.cz/porady/1185264473-poutni-mista/308298 380210003-svaty-jan-pod-skalou (acc. 26.05.2018); Michal Pešek, "Jak znovu ožil Svatý Jan pod Skalou - klášter, kostel a obec" (unavailable).

${ }^{10}$ Vide "Minuty z př́rody: Jeskyně sv. Ivana," http://www.ceskatelevize.cz/porady/11126999091minuty-z-prirody/215562220300052-jeskyne-sv-ivana/ (acc. 5.05.2018). 
čertů, kteři vyhnali poustevníka z Bílé Třemešné do Sv. Jana pod Skalou (2005; The Expedition to Search for the Czech Devils. The Temptation of Saint Ivan. Jaromír Štětina in the Sites of the Devils who Drove a Hermit from Bílá Třemešná to Sv. Jana pod Skalou). ${ }^{11}$

A humorous mood enters already in the first scene: a horse-drawn wagon that carries the filmmakers has the inscription "The Expedition to Search for the Czech Devil." Other scenes and commentaries appear as primitive jokes from Saint John under the Rock. On the other hand, under this ironic style linger serious questions: What does temptation mean today? What did it mean in the distant past? And, how do the Church, modern psychology, and ordinary people view temptation today? In that sense, the film is not an expedition to a mysterious underworld of other TV programs, but rather a journey to a sphere of modern meaning and function of ancient spiritual ideas; for instance, the movie uses "resilience" as a religious concept that expresses the human power to rise from a fall, although falling is inevitably bound to every human existence.

All those TV programs, although interesting, do not raise the question of contradicted narratives connected with the place. The authors do not try to show how those narratives compete with each other for dominance. Above all, it is not a unique problem of this place but a general problem of the Czech identity.

My approach is different because I see in Svatý Jan pod Skalou a point of narrative interference in which various discourses secretly compete with each other never to compose into a cultural structure, in which variable and various elements can coexist. Conversely, the victorious narrative takes it all, although only temporarily.

Let me sketch the long and turbulent history of Svatý Jan pod Skalou. The place is tightly linked with its patron saint, Saint John. Legend has it that the patron hermit settled in the village in the ninth century. He is said to have been the son of a Croatian king, so he was called "Croatian prince." This origin was questioned by Josef Vašica, a Czech theologian, Slavist, Biblist, literary scholar, translator, editor, and Catholic priest. Considering Saint John as a historical person, Vašica points out that the Elbe region, inhabited by Slavs, was his vernacular country. Vašica analyzed Saint John's importance for Czech culture in the Baroque, but his influence is not limited only to that period. ${ }^{12}$

11 "Pokušení svatého Ivana. Jaromír Štětina v osidlech čertů, kteří vyhnali poustevníka z Bílé Třemešné do Sv. Jana pod Skalou,” http://www.ceskatelevize.cz/tvprogram/hledani/?filtr[IDEC] $=204562215400016 \&$ filtr[obdobi] $=$ archiv (acc. 26.05.2018).

12 Josef Vašica, České literární baroko: Příspěvky k jeho studiu (Brno: Atlantis, 1995), 61-84. First edition: 1938. 
Saint John appears as a hero of the oldest Czech literary texts like the lost Staroslověnska legenda (The Old Slavonic Legend), ${ }^{13}$ known only from seventeenth-century Latin copies. The original manuscript dates back to 1096 the earliest, but the precise date and author remain unknown. Another medieval source that reveals information about Saint John is the fifteenth-century Latin Kapitulní legenda (aka Latin legenda), supposed to be nearly one century older. Those two legends served Václav Hájek from Libočany - the most popular Czech Baroque historian - as the basis of his Kronika česká (1541; The Czech Chronicle), once the most read book and the most important works about sixteenth-century literature in Czechia. Saint John's worship flourishing in Baroque inspired many first-rate artists like Bedřich Bridel, the author of Život sv. Ivana, prvního v Čechách poustevníka (1657; The Life of the First Hermit in Czechia, Saint John Under the Rock). Later, the figure of Saint John fascinated young Karel Hynek Mácha, the most outstanding Romantic writer in Czech literature and author of Poutník, Poustevník a Svatý Ivan (Pilgrim, Hermit, and Saint Ivan), ${ }^{14}$ as well as Karl Jaromír Erben.

This short sketch proves the importance of Saint John under the Rock for Czech culture, not to mention his popularity in many theater performances - especially by the Jesuit order - popular prayers, songs, and his influence on popular and elite forms of Czech culture. Moreover, there was a famous pilgrimage devoted to him, which spread his cult among the whole Czech society. Analyzing Czech identity without Saint John under the Rock would be incomplete and - what should be stressed - it was his devotion to God and spiritual values that have attracted the Czech to him for hundreds of years.

Surprisingly, the name of the hermit was Ivan, but the place for centuries has been called Svatý Jan pod Skalou, which is confusing. The legend has it that Saint John the Baptist appeared in the village when Ivan the hermit decided to leave, frightened by demons that followed him even to his cave where he expected to find shelter. It is said that Saint John the Baptist gave him as a sacred gift the stick that scared away the persistent demons.

Today, some interpret this legend in psychoanalytic code that allows one to see Ivan the hermit not as a historical person but the personification of human fears. In these readings, Saint John the Baptist is an alter ego of the hermit, his psychological complementation, which proves that we may overcome panic, horror, doubt, and despair. This interpretation emphasizes that people can find great power in themselves to vanquish their own demons. The village Svatý Jan pod Skalou is strongly marked by this legend and visitors often claim to find a kind of positive energy there, a kind of spiritual dimension connected with the place itself.

\footnotetext{
${ }^{13}$ Jiří Ševčík, Album svatoivanské (Praha: Vyšehrad, 2002), 40.

${ }^{14}$ Josef Vašica, op. cit., 66.
} 


\section{2.}

Saint John the Baptist who helped Ivan the Hermit to win his battle with demons is considered to be the patron saint of water - and this element plays an important role in making this place mystical. Even in fifteenth-century texts, the water from the local spring was considered "living water" for its healing and miraculous properties; appreciated for centuries, it became the subject of modern poetry. Such Czech poets as Ivan Slavík and Jan Skácel devoted their poems to the sacred water from the spring in Svatý Jan pod Skalou. Skácel's lyric Modlitba $z a$ vodu (Praying for the Water) ${ }^{15}$ conveys the local mood of reflection and tranquility in a particularly beautiful way. The poem describes "places that disappear year after year, where our sweethearts used to draw water, where hinds quenched their thirst, where the primrose bloomed, and where pilgrims bent over the cold spring to drink it from their palms." ${ }^{16}$ The unusual serenity of the poem reflects the meditative calmness of this area. It is important because some people perceive Svatý Jan pod Skalou as the cradle of the sacred, which managed to stand the test of time and history.

Svatý Jan pod Skalou reached the peak of its religious fame in the eighteenth century, when thousands of people partook in annual pilgrimages to place, and when the magnificent Benedictine monastery was built there. Commoners and crowned heads alike visited Svatý Jan pod Skalou, all seeking peace of soul and hoping to find it in where Saint Ivan the Hermit had left traces of his knees when he prayed. For years, the spectacular form of these pilgrimages and other manifestations of the local cult were dictated by a more universal style of Baroque religiosity. All this was discontinued by Joseph II's reforms which led to the liquidation of monasteries, including the Benedictine cloister in Svatý Jan pod Skalou.

The above is one of the layers of the place, tightly bound to Christianity. Of course, though aimed at the secularization of the state and introduced in a decisive manner, the reforms of Joseph II changed the public form of religiosity. However, the strong Christian tradition of Svatý Jan pod Skalou ought to have resisted more vigorously against secularization or even profanation of this place in particular. In my opinion, its exceptional history and importance for the Czech culture should have marked some limits of acceptable restructuring of the ancient Benedictine monastery formation and a new idea of how this place could be used. It was a sacred site throughout the centuries. However, Czech culture did not protect the place and the process of destruction had started long before the communists came into power.

\footnotetext{
${ }^{15}$ Jan Skácel, "Modlitba za vodu," in Básně [Poems], ed. Jiří Opelík, vol. 2 (Třebíč: Akcent, 1998-2008), 243-245. First edition: Odlévání do ztraceného vosku (Brno: Blok, 1984).

${ }^{16}$ Ibidem.
} 
It was the communist policy that is accused of secularizing the sacred places or even worse - exploiting them for a political aim in such a brutal and vulgar way that this blasphemous use should definitely annihilate their sacred. Looking at the history of the restructuring of the Benedictine monastery in Svatý Jan pod Skalou - proceeding without any protest for the last decades of the nineteenth century and at the beginning of the twentieth century - we should think that there was little difference between the communist approach to sacred places and that of Austria-Hungarian policy. Long before the communists took power, the sacred place had been used in a way which defied its character. Before the First World War, the monastery was turned into a tannery, then a spinning mill, and a paper factory; all kind of dirty and stinking production that damaged not only the monastery but also the rest of the holy place. Profoundly.

In a sense, the "better" time for Svatý Jan pod Skalou began in 1904, when an elegant and exclusive spa was organized there. On old postcards, one can see beautifully dressed people living their luxury lives in the posh hotel that used to be the old monastery; one can see them having a social life in the rearranged monastic garden, adapted to the needs of the beau monde. The father of a well-known Czech writer, Karel Čapek, used to work in the spa. At the time, nothing made people think of the past of this place, the time when not the body but the soul was the subject of care. I do not see a problem in the fact that the place was used in that way; the problem lies elsewhere. The new use of the place created a new cultural layer that scrupulously covered the old one. The history of Svatý Jan pod Skalou had lost its continuity because - in such a fashionable place - nobody wanted to remember about the old hermit and his idea of strict, ascetic life devoted to prayer nor wanted to keep in mind the thousands of people who formerly used to visit the site with their thoughts and dreams about something which is eternal.

The next period for Svatý Jan pod Skalou began when it was used by an institution ideologically close to the Church that sought to educate future Christian teachers, in 1914-1942. The teaching institute - established in the

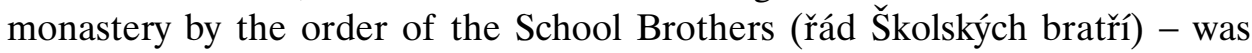
known to be extremely severe and resemble a penitentiary enterprise more than a pre-university school. This stage of history of the place created a new cultural layer that shows Churchs' unsuccessful modernization efforts. ${ }^{17}$ The next stage was connected with a mental hospital, which operated there between 1942-1945, during the Second World War.

The crucial moment was when the war ended and the communists in power organized in the old monastery a labor camp Tábor Nucené Prací (TNP).

${ }^{17}$ Students of the Catholic school commemorated Jan Hus with a memorial stone on July 6 , 1919. It is said that this manifestation was against their Catholic teachers. 
Turning monasteries into labor camps was part of the communist secularization policy connected with its program to eliminate religion from social consciousness and remove the influence of the Church. After February 1948, the Church was the only institution not completely subordinate to communist hegemony. Thus, on July 13,1949, a special committee (Alexej Čepička, Viliam Široký, Václav Kopecký, Vladimír Clementis, Jiří Hendrych, Zdeněk Fierlinger) decided to list all Czech monasteries and prepared a project to use them to strengthen communist power. With the aim to destroy the community of believers - clergymen and the laity - and extinguish the spirit of resistance, the communists planned to convert churches into labor camps or prisons as a visible sign of a new political order. The Church authority was to be annihilated so that those who dared to doubt the communist domination were confronted with its power whenever looking at the former sacred places subdued and deprived of sanctity. In 1950, there were 32,600 prisoners in Czechoslovakia and nearly third of them for political reasons $(11,000) .{ }^{18}$ That is, this "theatre" of seizing sacred space was expected to have a huge "audience" - not only "inside" different camps and prisons organized in old Church buildings but also "outside" and among those who had to look at them.

3.

The labor camp in Svatý Jan pod Skalou existed until December 31, 1950. ${ }^{19}$ At that time, communist policy towards TNPs began to change and some of them were closed or transformed into regular prisons. The latter was the case of Svatý Jan pod Skalou. The communist administration reconstructed and reorganized the monastery for it to serve as a jail, initially for ill prisoners, then as women's place of isolation, ${ }^{20}$ and finally as "prison number seven" for Prague area, with 235 places for its "guests." At the time, Svatý Jan pod Skalou the nearest area was completely inaccessible: cars could not stop nearby, photographing was strictly forbidden, people could not approach it. In such form. the place lasted until 1955, when it was closed and, instead of it, the administration organized there a school for the members of the Czech Security Service (StB).

To commemorate that period, a memorial plaque dedicated to political victims was unveiled there in 2005 . The plaque speaks of the severe conditions of the TNP, where some people died from overwork in the local quarries, as well as about the extremely cruel treatment and persecution of prisoners in the later jail.

${ }^{18}$ Dušan Janák, Aleš Kýr, "Nástin vývoje československého vězeňství v letech 1948-1989," Historická penologie, no. 5 (2004): 1-5.

${ }^{19}$ Alena Kafková, “Z historie kláštera Sv. Jan pod Skalou,” Historická penologie, no. 3 (2003): 12-13.

${ }^{20}$ Ibidem, 13. 
According to the authors of the memorial plaque, the prison "belonged to the most oppressive jails of the time." ${ }^{21}$ However, the truth about that jail is neither obvious nor unequivocal. All the available information about the jail are incomplete and contradictory. In 2003, Alena Kafková wrote that - besides archival materials - some knowledge about the place should remain in the local community, ${ }^{22}$ but she did not resolve doubts about how severe the jail was. However, some information in her article suggests that the place was not as horrible as it is remembered, because it was the jail for the sick, the old, and women. Moreover, the short period of TNP left no strong evidence of cruelty and the place does not appear alongside other TNPs whose strict regime is confirmed by historical sources (Jáchymov, Ostrava). People were sent to Svatý Jan pod Skalou in connection with "Akce T-43," an action directed at the richest owners deprived of their wealth before imprisonment. So only the millionaires were "honored" with the right to stay in the camp at Svatý Jan pod Skalou and this - partly absurd - situation was employed by the well-known Czech writer, Bohumil Hrabal, in his novel Obsluhoval jsem anglického krále (I Served the King of England), in which he describes the camp in a grotesque manner.

As I mentioned above, the severity of the jail organized in place of TNP is uncertain. The memorial plaque describes the place as an extremely brutal penitentiary. Obviously, it was not a sanatorium as the monastery was built on a marshland, which resulted in heating problems and moist, cold cells. Like other prisons in ex-monasteries, Svatý Jan pod Skalou was characterized by such difficulties awful hygienic conditions and a shortage of toilets. Food was poor and monotonous. On the other hand, arrested for Catholic activism and sent to the to the penitentiary after a long investigation, Antonie Hofmanová presents Svatý Jan pod Skalou in a different manner. The reason to place her there was that she suffered from tuberculosis. Her first impression when approaching the prison is:

Rocks and rocks again. At the top of one rock, I saw the cross and before it the monastery, which looked as a romantic picture from the Alps. But that instant, anton ${ }^{23}$ passed the prison gate, the driver greeted the guard, while [Saint] John [under the Rock] looked at the door closing after the two as she [Hofmanová] became a spellbound princess who would never get outside this gate again. ${ }^{24}$

${ }^{21} \mathrm{http} / /$ www.pametnimista.usd.cas.cz/svaty-jan-pod-skalou-pametni-deska-politickym-veznum/ (acc. 26.05.2018).

${ }^{22}$ Alena Kafková, op. cit., 12.

${ }^{23}$ A police car used for transporting prisoners is called "Anton." One interpretation of this name was written down by Hašek in his famous novel The Good Soldier Švejk.

${ }^{24}$ Antonie Hofmanová, Bud'me prostí jako holubice. Vyprávění katolické aktivistky o svém vězněnív padesátých letech (Praha: 1991), 60; cit. per Aneta Doležalová, Církevní procesy v 50. letech na př́kladu Antonie Hofmanové, https://theses.cz/id/9cecpv/STAG67029.pdf (acc. 25.05.2018). 
This "romantic opening" finds no continuity in style, however Hofmanová notices that her cell was bigger than the one in Prague jail and the room was clean: "Two rows of clean beds with quilts and sheets, facing each other, resembled a hospital space, a toilet was enclosed with a white screen and the wooden floor was cleanly scrubbed." ${ }^{25}$ Hofmanová had the right to correspond with her family and even some meetings with the family were allowed, which did not happen in her previous jail. The stay was an important experience for her, although conversations were controlled and no physical contact with the visitor was permitted. Prisoners in Svatý Jan pod Skalou could receive (controlled) parcels with food from families. They were investigated but - in opposition to her previous jail in Hradec Králové - Hofmanová experienced neither torture nor physical punishment. Seriously ill people were not forced to do heavy work and could use the library. Money received by prisoners were used for buying food, because the one in jail was very bad. Of course, meals of bad quality and quantity were not suitable for ill people, but the fact that they could protest about it and demand better alimentations proves that it was not one of "the most oppressive jails of the time," as claims the memorial plaque. A prisoners' protest resulted in controlling of their living conditions and food improvement for a time. They even started to serve dietary meals. I do not intend to suggest that the "spellbound princess" was happy and spent a relaxing holiday at the jail. But the truth about the place seems less dramatic as it is widely believed.

It is worthwhile to establish the facts about the Svatý Jan pod Skalou monastery in the communist period since there are two contradictory narratives bound to the place so important for Czech culture. The martyr discourse above - which I tried to verify - collides with the grotesque mockery by Hrabal. In his novel Obsluhoval jsem anglického krále, Hrabal shows the camp as the place where everything was "inverted" and became a form of theater, in which guardians and prisoners switched their roles. There is no place for martyrdom in Hrabal's vision. Obviously, the writer has his right to alter reality, and Hrabal uses this right to transform the reality into a literary vision, not mimetic but vaguely "similar" to the real world. However, I believe that even Hrabal would not have dared to show a place that witnessed death and pain as a playful theater where nothing is serious. His interpretation confronts us with the questions: What the camp in Saint John Under the Rock really was? Which narrative about it is true?

The few historians who research the subject of that labor camp and people who left their testimonies about it disagree with Hrabal's descriptions. On the other hand, literary critics of his works raise no question about how faithful Hrabal is to historical reality. Different narratives are different pieces of the

\footnotetext{
${ }^{25}$ Ibidem, 54.
} 
mosaic of history. Václav Žmolík, a Czech journalist, publicist, screenwriter, radio and television editor, said that the place fascinated him because "everything is different there." Consciously or not, Žmolík followed Hrabal's idea. Wandering about the city, the director enjoys observing a portrait of Emperor Josef II in one of the houses, instead of a picture of the incumbent president at the time, Václav Havel. Žmolík also mentions the ironic name of the pub, "Elementary school," as well as the grotesque story of a tombstone in the local cemetery. Someone paid for the construction of the grave and the monument, who then buried there a bottle of vodka and himself went on a trip around the world. All this is funny and presents a typical Czech sense of humor. The issue of conflicting narratives is in some way also funny but, on the other hand, absolutely serious.

\section{References}

Halík, Tomáš. Víra a kultura - pokoncilní vývoj českého katolicismu v reflexi časopisu Studie. Praha: Zvon, 1995.

Janák, Dušan, et Aleš Kýr. "Nástin vývoje československého vězeňství v letech 1948-1989." Historická penologie, no. 5 (2004): 1-5.

Kafková, Alena. "Z historie kláštera Sv. Jan pod Skalou.” Historická penologie, no. 3 (2003): 10-14.

Kuchař, Jiří, et Václav Vokolek. Esoterické Čechy, Morava a Slezsko. vol. 1. Praha: Eminent, 2002.

Kuchař, Jiř́, et Václav Vokolek. Esoterické Čechy, Morava a Slezsko. vol. 4. Praha: Eminent, 2005.

Ševčík, Jiří. Album svatoivanské. Praha: Vyšehrad, 2002.

Skácel, Jan. "Modlitba za vodu.” In Básně [Poems], ed. Jiří Opelík, vol. 2. Třebíč: Akcent 1998-2008, 243-245.

Skalický, Karel. "Prolegomena k budoucí filozofii českých dějin.” In Za nadějí a smysl. Praha: Zvon, 1996, 130-161.

Vašica, Josef. České literární baroko: Př́spěvky k jeho studiu. Brno: Atlantis, 1995.

\section{Internet Sources}

"Minuty z př́rody: Jeskyně sv. Ivana." Filmed 2017, https://www.ceskatelevize.cz/porady/ 11126999091-minuty-z-prirody/215562220300052-jeskyne-sv-ivana/ (film unavailable).

Ciprová, Inka, et Jaromír Vašta. "Příběh poustevníkova lože." Commented by František Nepil. Filmed November 1995, Česká televize 2015 (film unavailable).

Hofmanová, Antonie, Bud'me prostí jako holubice. Vyprávění katolické aktivistky o svém věznění v padesátých letech, Praha 1991, p. 60. This book is unavailable. I quote after: Aneta Doležalová, Církevní procesy v 50. letech na př́kladu Antonie Hofmanové (Hradec Králové, 2015), 54, https://theses.cz/id/9cecpv/STAG67029.pdf. 
Lederer, Alan. "Pokušení svatého Ivana. Jaromír Štětina v osidlech čertů, kteří vyhnali poustevníka z Bílé Třemešné do Sv. Jana pod Skalou.” Filmed 2005, http://www.ceska televize.cz/tvprogram/hledani/?filtr[IDEC]=204562215400016\&filtr[obdobi]=archiv.

Novák, Ján. "Počesku: Svatý Jan pod Skalou, Ves pod patronátem poustevníka, který se ovšem nejmenoval Jan.” Filmed March 2001, Česká televize, http://www.ceskatelevize. cz/ivysilani/1037067545-pocesku/201322225720003-svaty-jan-pod-skalou.

Pešek, Michal. "Jak znovu ožil Svatý Jan pod Skalou - klášter, kostel a obec.” Filmed 1992 (film unavailable).

Somr, Josef, et Ladislav Lakomý. “Cyklus o putování po známých i méně známých místech hlubokých tradic.” Filmed 2008, http://www.ceskatelevize.cz/porady/1185264473poutni-mista/308298380210003-svaty-jan-pod-skalou. 